\section{Integration problems}

Science has a fighting chance of survival in the eastern part of Germany. But will it seize the moment?

WHAT is to be done to integrate the research establishment of East Germany, hitherto supported from Berlin, with that of West Germany, supported from Bonn? It has been plain since the outset of the reunification project that there would be serious difficulties in absorbing East Germany's stalinist Academy of Sciences into the quite different pattern of research supported by, among others, the Deutsche Forschungsgemeinschaft (DFG) and the Max-Planck Gesellschaft (MPT), many of which were vividly made plain by the letter from Dr Werner Franke last week (Nature 346, 603; 1990). Put bluntly, the problem in East Germany is that almost all research is supported through the academy and carried out by institutes whose tenured members conduct research which is often second-rate and whose personal reputations have been sullied by their association with the regime whose last vestiges will disappear with the elections planned for Deceniber. What will happen to the eastern academy institutes after that?

Wisely, the West German research minister, Heinz Riesenhuber, has agreed that 18 months should pass before the fate of the institutes and their researchers is finally decided. To have acted otherwise would have been to emulate old-fashioned East German heavyhandedness. The hope is that the interval will allow a sober evaluation of the parts of the old academy system worth saving. But the process is bound to leave scars.

So how should this breathing-space be spent? One possibility is that the academy system may be able to shrink itself to a more modest size. That is what Riesenhuber himself expects. The snag is that the end result would be a series of institutes not necessarily of a kind that could be integrated into the West German system. It would be much better that the interval should be spent in allowing elements of the research enterprise in the east, from individuals to whole institutes, who consider they have a legitimate claim on funds from the West should use the interval to apply for support from DFG, MPG or other western sources. That would also be a painful process, but one that people could understand.

However the integration is accomplished, it will not be free from recrimination. Under the old regime, the patronage of the stalinist government was a necessary requirement for even modest success in science. People at odds with the ideology were unable to meet their peers by travelling abroad, and were often denied facilities for research. To what extent, now, should there be positive discrimination in favour of these people? And may not those who sold their soul to the old regime also be seen as victims? That is a question that will keep the evaluators awake at nights, not only in East Germany but in the rest of reforming Eastern Europe.

684

\section{Untransparent grants}

The British Medical Research Council will have to be more open about its research policy.

DURING the past ten hard years, the British research councils have miraculously managed to keep the respect of their constituents, researchers at British universities, by the transparent fairness of their decisions. Even when there has not been enough money to go around, grant applications have been scored with apparent objectivity by the peer-review system, and many applicants destined for disappointment have been told that their proposals would in normal times have been supported. But there are now signs that the strains on the system may be undermining it. The fuss about the refusal of the Medical Research Council (MRC) to renew a research grant at Cambridge (see opposite) is a sign that strains on the British research-support system are now insupportable.

The circumstances are not entirely clear, although it seems to have been determined that the ten-strong Medical Cryobiology Group (which costs $£ 250,000$ a year) is to be disbanded. The research bears on the physics and the physiology of the preservation of organs for transplantation in which Cambridge is a leading British centre. Referees (not exclusively from Britain) appear to have given the work at Cambridge glowing testimonials, but the MRC Cell Board seems to have offset these high opinions with the conclusion that the research, while interesting, lacks urgency and, indeed, the potential for making a mark on research internationally. At least some members of the subcommittee that reached that conclusion are now dissenting from the decision to close down the research group, saying that their opinions have been misrepresented. Transplant surgeons, in Britain and elsewhere, are meanwhile up in arms.

The issue of principle raised by these developments concerns the degree to which grant-making bodies such as the MRC must make their decisions intelligible to the wider world. Especially when research funds are as scarce as they have become in Britain, nobody expects that all decisions can be clear-cut, or determined exclusively by scientific quality. Questions of whether the research concerned can be afforded a place in some national pattern of activity are also legitimate and proper. What the MRC appears on this occasion not to have appreciated is that decisions based on these broader considerations must also be argued publicly if they are to make sense to those directly affected and to the research community in general. It will be disgraceful if the MRC has sought to avoid the difficulty of justifying an unwelcome decision by concealing its reasons for reaching it, which is the obvious inference of the Cell Board's report. In any case, the MRC has no choice but to argue the case for strategic decisions publicly. Or rather, if it chooses to act otherwise, it must recognize that it will lose the support of its research community. 